\title{
Úvodní slovo předsedy ČSCH
}

\section{Milé kolegyně a kolegové, vážení čtenáři,}

rychle jako voda uplynulo osm let od chvíle, kdy Vás oslovil na tomto mistě v Úvodníku našich Chemických listì prof. Jan John, jakožto nově zvolený predseda České společnosti chemické (ČSCH). Dnes se dostalo této pocty a dưvěry mé osobě.

Něz se začnu věnovat chemické komunitě a souvisejicím záležitostem, rád bych Vám všem poprál štastný a úspěšný vstup do nového roku. Bývá zvykem prát i hodně zdraví a vétšinou to bereme jako formalitu. Na počátku roku 2022, obdobně jako na počátku roku minulého, takovéto prání nabývá velmi reálných rozměrü. Ve chvílich, kdy piši tyto řádky, počty pozitivně testovaných osob na Covid-19 v nejrüznějšich mutacich podstatně převyšují hrozivou vlnu z jara 2021. Vime však, že di̊ležité nejsou absolutni počty, ale osoby ohrožené př́mo či nepřimo na životě. Dovolte mi proto, abych vyslovil naději, že dalši vlny, pokud prijdou, budou vykazovat podstatně nižši statistické charakteristiky (výšku, šikmost, špičatost) jak co do absolutniho počtu, tak počtu zemřelých.

Asi tak jako každý, kdo se ujímá jakékoliv funkce, premýšli o tom, jak pokračovat v práci svých předchůdců (nebo jak se od nich odlišovat). Moje úloha je o to těžši, že navazuje na práci tak úspěšných předsedì, jako byli prof. Vilím Šimánek, prof. Jitka Ulrichová, prof. Jan John, kteři významně prispěli ke stabilizaci a rozvoji jak jednotlivých odborných skupin a poboček, tak ČSCH jako celku. Dovolte mi, abych jim touto cestou vyjádřil poděkováni za manažerskou práci nezištně odvedenou ve prospěch ČSCH, která $i$ diky nim patři mezi aktivni odborné společnosti jak $v$ rámci Českého svazu vědeckotechnických společností (ČSVTS), tak i Rady védeckých společností České republiky (RVS). Věrim, že se budu moct opřit o zkušenosti a pomoc dosavadního predsedy ČSCH, prof. Johna, který tuto funkci svědomitě vykonával po dvě volebni obdobi a nyní bude pưsobit jako 1. mistopředseda a ex offo člen Předsednictva $\check{C}$ SCH.

I přesto, že členství v naši společnosti je dobrovolné, ČSCH registruje v současné době bez mála 1300 individuálních členů z České republiky, Slovenska a jiných států. Jejich aktivity jsou zaměreny jednak regionálně (diky pobočkám v Brnè, Olomouci, Ostravě, Pardubicích, Plzni a Zlině), jednak v souladu s náplní 26 odborných skupin (OS). Kromě toho začala v poslednich letech velmi aktivně puisobit sekce ČSCH pod názvem Asociace mladých chemiků.

Dovolte mi, abych svou pozornost věnoval dvěma nenápadným, ale přesto př́mo esenciálním součástem $\check{C}$ SCH, tj. sekretariátu ČSCH a redakci Chemických listů (jmenovitě se jedná o RNDr. Helenu Pokornou, Ing. Alenu Vlkovou a Ing. Radmilu Řápkovou). Uvedené složky poskytuji naprosto nezbytné a neocenitelné zázemí, podporu a opěrný bod pro činnost OS, poboček, Hlavního výboru,
Předsednictva a jsou nepostradatelným opěrným bodem předsedy ČSCH.

ĊSCH je v současné době plně zapojena do struktur Evropské chemické společnosti (European Chemical Society - EuChemS), řada našich členů zastupuje ČSCH vdivizich a pracovnich skupinách EuChemS. Clenové ČSCH aktivně pracují v řadě dalšich mezinárodnich organizaci

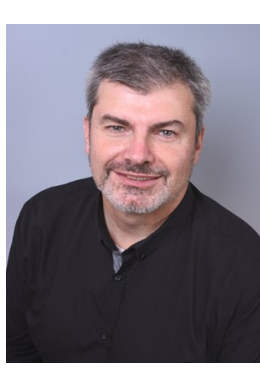
European Chemistry Thematic Network (ECTN), European Chemist Registration Board, Chemistry Eurobachelor Label Committee, International Society of Electrochemistry atd. ČSCH zastupuje české chemiky v nékterých dalšich mezinárodnich organizacich, zde je třeba zminit zejména International Union of Pure and Applied Chemistry (IUPAC), vjejichž divizich a výborech aktivně působi samostatně rada českých chemikư, a dále International Union of Food Science and Technology (IUFoST). Z hlediska prestiže a financování činnosti ČSCH se jako velmi důležitý jeví spoluvlastnický podíl v evropských časopisech v rámci konsorcia Chemistry Europe (drive ChemPubSoc Europe), kde prof. Vlastimil Vyskočil působi jako člen panelu redaktoru konsorcia vydavatelu.

Dovolte mi krátce se zastavit u dvou časopisů vydávaných ČSCH, jmenovitě Czech Chemical Society Symposium Series (CCSSS) a českého národního časopisu s bohatou historií, Chemických listi̊ (ChL). Zatímco CCSSS má jasně definovanou, řkněme nekonfliktní roli mezi ostatními časopisy (publikuje abstrakty a plné texty přispěvků z konferenci a sympózii pořádaných ČSCH), ChL se nacházi ve velmi složité situaci. Podle Web of Science i Article Influence Score (AIS) jsou ChL razeny do nejnižšiho kvartilu a šance na razantní posunutí směrem vzhi̊ru je v nedohlednu. Soutěživé univerzity, a ještě více po světové proslulosti toužici ústavy Akademie věd, $v$ drtivé většině bud' zakazují svým pracovnikuim publikovat $v$ časopisech mimo první polovinu $v$ žebričcku úspěšnosti (kvartily Q1 a Q2), nebo blahosklonně nezapočtou články publikované v ChL do hodnoceni zaměstnanců. Avšak najdou se i př́pady, kdy jeden článek v ChL musí být vyvážen více než jedním článkem publikovaným v časopise v prvnim kvartilu úspěšnosti Q1. To vše ústí v situaci, kdy redaktoři (zde je potřeba ocenit sisyfovské úsili prof. Jiřiho Barka) vymýšli nová a nová témata, která by prilákala dalši prispěvatele, a téměr jednotlivě je obcházeji a přesvédčují. Nelze však úplně z tohoto nepríznivého stavu vinit pouze autory „Metodiky hodnoceni výzkumných organizaci a programú účelové podpory výzkumu, vývoje a inovaci“"(ve zkratce „,Metodiky 17+“, prípadnè následujícich), kteř́ nechtěji mj. úmyslně protěžovat jeden z jazykù. Je potřeba presvédčit vedení jednotlivých institucí, která jsou zodpovědná za sestavováni pravidel evaluací, že 
je třeba vyjmout české národní časopisy (to jest časopisy vydávané v českém, prípadně ve slovenském jazyce) z množiny hodnocených časopisů a zar̆adit je do zcela nové kategorie. O vývoji a směrováni ChL v budoucnosti pojednává podrobněji článek šéfredaktora Chemických listů prof. Vyskočila: Chemické listy ve světle dnešni doby ${ }^{l}$.

Před Hlavním výborem, ale i OS, pobočkami a vlastně celou ČSCH stojí nejen řada nových úkolì, ale i řešení dlouhotrvajicich problémů. Mezi ty nejzávažnějši patři generačni problém, který zmiňoval již můj předchi̊dce, prof. John, ve svém Úvodním slovu v ChL při nástupu do funkce v roce 2014. Věkový průmèr členů ČSCH není rozhodně takový, aby nás mohl naplňovat optimismem. Je potřeba hledat vhodné zpuisoby motivace mladých chemi-

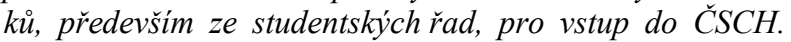
Snižený konferenčni poplatek na sjezdy chemických společnosti nesmi být jedinou motivací. V tomto ohledu by chtělo Předsednictvo ČSCH vice spolupracovat s Asociací mladých chemikü, kteři nám, již dávno ne dvacetiletým, pomohou lépe pochopit problémy mladšich věkových skupin a zpưsoby, jak s nimi komunikovat, jakými prostředky propagovat naše cíle a jak je motivovat nejen ke vstupu, ale především k aktivní práci pro ČSCH a celou chemickou komunitu.

Tak jako v jiných oblastech lidského života by nemělo být cilem jedince, $v$ tomto prípadě funkcionáre ČSCH na jakékoliv úrovni, pouze zastávat funkci od svého zvoleni až do odchodu z aktivního působení, aniž by si vychoval svého nástupce, který by pokračoval v jím nastoleném trendu, znal všechny problémy spojené s vykonávanou funkcí apod. Vyzývám proto nás všechny věkově pokročilejši $k$ výchově mladé generace našich nástupců. To platí nejen pro $\check{C} \mathrm{SCH}$, ale $i$ pro mezinárodní organizace, $v$ niž je ČSCH členem (napřr. EuChemS) nebo v nich zastupuje české chemiky (napřr. IUPAC). Je potřeba, aby dřive či později nevyhnutná generační obměna nepredstavovala zlomový bod, ale spojité pokračováni aktivit ČSCH.

V struktuře ĆSCH jsou OS/pobočky, které jsou velmi aktivni (pro ČSCH a celou chemickou komunitu). Na druhé straně máme OS/pobočky, které existuji v seznamu na webových stránkách, ale jejich činnost je bud' pouze formální, nebo dokonce vi̊bec žádná. Mezi cille, které si Předsednictvo vytyčilo, patři revitalizace takovýchto součástí ČSCH. Nikoliv za cenu dovedného stavěni Potěmkinových vesnic (tj. vykázání formálních aktivit, které členové vykonávaji již pro svého kmenového zaměstnavatele z titulu svého pracovního úvazku, již dávno existujici vzájemné spolupráce mezi vysokými školami a obdobnými institucemi nebo organizování soutěží, konferenci ve spolupráci s jinými již fungujicimi skupinami). Jedná se nám o vytvá- ření nových aktivit, atraktivnich nejen pro dosud pasivni členy ČSCH, ale i pro širokou chemickou obec. Řečeno slovy klasika: „Pracuj každý s chutí usilovnou na národu roli dědičné, cesty mohou býti rozličné, jenom vůli všickni mějme rovnou "(J. Kollár: Slávy dcera).

Dovolte mi vyjádřit svioj názor na dalši oblast směrování ČSCH. Pokud se podivám po realizovaných aktivitách Společnosti, jsou směrovány ve velké mirre na vysoké školy a jejich studenty (nechtěl bych v žádném prripadě pominout podil ČSCH na organizaci Chemické olympiády či popularizačnich akcí, jako je „Chemie a dalši prírodní vědy na Slezskoostravském hradě" apod.). V souladu s tímto zjištěním neni překvapujicí, že počet členů společnosti, kteřr nejsou studenty ani nepưsobi v akademické sfére, neni rozhodně vysoký. Spolupráce mezi akademickými pracovišti je bezesporu na světové úrovni a drtivá vétšina akademických pracovniků má přehled o nejnovějšich poznatcich v oblasti základního výzkumu. Současnè však často netuší, jaké průmyslové chemické podniky se nacházeji v jejich regionu či oblasti jejich zaměrení, jaké postupy, metody a prístroje se v nich použivaji, jaké maji požadavky na nově nastupujici absolventy škol apod. Nefunguje tak zpětná vazba pro úpravu učebnich osnov. A právě v tomto směru by mohla ČSCH sehrát velmi významnou a pozitivní roli.

Rád bych z tohoto mista pozdravil $i$ naše kolegy ze Slovenskej chemickej spoločnosti (SChS), se kterými nás poji mnohé profesní i osobni kontakty. Byl bych rád, kdyby se nám $v$ následujicich letech podařilo zintenzivnit vzájemné styky, spolupráci, výměnu zkušeností a mnohé jiné.

Jsem si vědom, že se nám pravděpodobně nepodaři zrealizovat všechny vytyčené úkoly, ale pripomeňme si citát Svatopluka Čecha: „Sláb jenom ten, kdo v sebe ztratil víru, a malý ten, kdo zná jen malý cíl. “ A nezapomínejme že „často tichá pastuchova chyžka více pro vlast müže dělati nežli tábor, z něhož válčil Žižka “ (J. Kollár: Slávy dcera).

Závěrem bych Vám, vážení čtenáři našeho jediného impaktovaného chemického národniho časopisu, jménem svým, Předsednictva i celého nového Hlavního výboru ČSCH popřál ještě jednou mnoho štěstí, úspěchů, ale především pevné zdraví v novém roce 2022.

Tomáš Navrátil Předseda $\check{C} \mathrm{SCH}$

\section{LITERATURA}

1. Vyskočil V.: Chem. Listy 115, 497 (2021).

- Navrátil T.: Chem. Listy 116, 1-2 (2022)

- https://doi.org/10.54779/chl20220001 